\section{DIGITAL COMMONS \\ @ UNIVERSITY OF SOUTH FLORIDA}

\section{ABO: Interactive Journal for Women in the Arts, 1640-1830}

Volume 5

Issue 2 Volume 5.2 (Fall 2015)

Article 3

2015

\title{
Review of Marjo Kaartinen, Breast Cancer in the Eighteenth Century
}

Marie Mulvey-Roberts

University of the West of England, Bristol, marie.mulvey-roberts@uwe.ac.uk

Follow this and additional works at: https://digitalcommons.usf.edu/abo

Part of the English Language and Literature Commons, Feminist, Gender, and Sexuality Studies Commons, History of Science, Technology, and Medicine Commons, and the Women's History Commons

\section{Recommended Citation}

Mulvey-Roberts, Marie (2015) "Review of Marjo Kaartinen, Breast Cancer in the Eighteenth Century," ABO: Interactive Journal for Women in the Arts, 1640-1830: Vol.5: Iss.2, Article 3.

http://dx.doi.org/10.5038/2157-7129.5.2.3

Available at: https://digitalcommons.usf.edu/abo/vol5/iss2/3

This Reviews is brought to you for free and open access by Digital Commons @ University of South Florida. It has been accepted for inclusion in ABO: Interactive Journal for Women in the Arts, 1640-1830 by an authorized administrator of Digital Commons @ University of South Florida. For more information, please contact digitalcommons@usf.edu. 


\section{Review of Marjo Kaartinen, Breast Cancer in the Eighteenth Century}

\section{Keywords}

breast, cancer, women, medicine, disease

Creative Commons License

(c) (i) $\odot$

This work is licensed under a Creative Commons Attribution-No Derivative Works 3.0 License. 
Marjo Kaartinen, Breast Cancer in the Eighteenth Century. London: Pickering and Chatto, 2013. xii, 256pp. ISBN 978-1-84893-364-4

Reviewed By Marie Mulvey-Roberts

University of the West of England, Bristol

Within Galenic medicine, cancer was regarded as a women's ailment, despite being common to both sexes. Even though men suffered breast cancer, it was associated more with the female. By the early modern period, the disease was seen as an attack on "the ornaments of the female sex" and invariably on femininity itself (42). Marjo Kaartinen powerfully conveys how much it was feared and generally assumed to be a death sentence during the eighteenth century. She builds on the work of historians of medicine, such as Roy Porter, who have examined the experience of patients in early modern medicine. Kaartinen provides a detailed exploration of the experience of the cancerous body, conveyed through the writings of patients and physicians. She goes into forensic detail regarding symptoms, diagnosis and treatment, as well as the pain, emotions and immense suffering associated with this dreaded disease. This study, which is the first of its kind, is a moving account of the pitiful and often heroic history of a terrible affliction, which beset so many eighteenthcentury women and their families. It is not only a story of pain, disfigurement and the prospect of an agonising death, but also one of stoicism, endurance and survival. Of paramount importance is the experience of the sufferer told through the four chapters, which focus on diagnosing the disease and its causes, the treatment of cancer, women's agency and choice of treatment and finally the pain and emotions of the suffers.

Readers coming to this book are likely to be familiar with the harrowing account of Fanny Burney's mastectomy without anaesthetic. This still remains the most lucid and detailed description of the horrors involved. As a member of the upper classes, Burney had the best surgeons and medical equipment. Kaartinen has dug into the case histories, private letters and diaries of a range of women across the social classes in order to determine how they too coped with the disease and its treatment. She looks at how medical discourse matched the means by which patients communicated their malady, so that, for example, their "darting pain" was reworded into the doctor's "dolor lancinans" (97). Kaartinen also indicates how the diagnosis of a physician or surgeon increasingly came to incorporate the patient's own story. Among the women telling their own story of the disease are several important writers. 
Jane Barker (1652-1732), the poet and novelist, and fellow author, Mary Astell (1666-1731), read their bodies in the knowledge that "A growing lump and 'pricking pain' told a tale"" (57). Astell kept her cancer secret until she decided that the time had come for the malignant breast to be cut off thereby retaining control over her body in the treatment of the illness.

This example highlights one of Kaartinen's most important contributions to the history of medicine and culture, which is to dismantle assumptions regarding the relative passivity of eighteenth-century women when faced with this life-threatening malady. She reveals the extent to which women were active agents in deciding on their treatment and how, for the most part, they were well-informed, availing themselves of information from lending libraries and sometimes resorting to women's medicinal recipes. Women could also be unruly by going against the advice of a physician and it was always women, themselves, who made the decision as to whether or not to have their breast surgically removed. Their choices lay in pursuing orthodox medicine, quackery, folk-medicine or simply to bypass any form of treatment. For home remedies, all manner of poultices were applied, many of which proved ineffective. But there were success stories. Hannah Murray was told by skilled surgeons that she had contracted the worst case of breast cancer. Fortunately she was directed towards a gentlewoman who had cured herself of cancer and instructed her to apply Pokeweed to the tumour, which resulted in a cure. This highly poisonous plant acts as a powerful caustic and is still being used and researched in the fight against cancer today. By recording Murray's account of her treatment, John Patterson was passing on the knowledge of women to his medical colleagues. Upper-class women were known to prepare medicines in their distilling houses and the recipes were often handed down the generations to family members, sometimes finding their way into popular handbooks. At the end of the century, the unusual recommendation was made to swallow two or three green lizards daily in the hope of a cure. Other medicinal substances included viper broth and the ashes of frogs to be made into an anointment. King of the cancer pharmacopoeia was mercury. Another poison in use against the disease was hemlock, while fashionable medications included millipedes and sarsaparilla. Quacks favored caustic substances. These and other forms of cautery, such as the use of hot irons, were also used by doctors. Caustic substances were recognised as extremely painful, particularly since they were applied over a prolonged period, whereas the last resort of the knife was less protracted, though more agonising in the short term and high risk for the patient. One way of dealing with pain was to turn to religion. This could serve 
as a form of medicine by enabling believers to regard their sufferings as Christ-like. The anonymous author of the poem "Ode to Melancholy" (1782) dedicates it "to the memory of a lady who died of a cancer in the breast." The sufferer in the poem is described as conquering her pain, disease and death through her Christian faith. "With more than female tenderness" and "With more than manly fortitude", she transcends sex and gender in living "superior to the sense of pain" and "In keenest tortures undismay'd" (108-9).

Kaartinen describes the gothic horror of this tormenting disease, often crablike in its appearance, which ate away at a patient, eventually consuming her. The ulceration of the tumour marked an excruciating and desperate stage in the course of the illness, described as thrusting forth "hard and painful lips" (97). The metaphor, which aptly captures the idea of consumption from within, also corresponds to descriptions of drinking from the tumour for experimental purposes, as in the case of the physician Samuel Smith, who tasted "the Juice" contained in the glands of a large amputated breast (20). It was generally believed that this fluid, thought to be "sharp and corrosive" was poisonous (20). A related liquid is curdled breast-milk, which was believed by Burney to have been responsible for her tumour. More generally breast cancer was blamed on a variety of causes including infertility and celibacy. The latter has some credence today in regard to pregnancy and breast-feeding, which are thought to reduce the risk of cancer.

Whilst eighteenth-century medical practice and theory are well explained in the book, some comparative information in regard to what is now known would have provided a useful contextual framework. For readers who are not oncologists, the confirmation as to whether some of the assumptions made about the disease were actually correct or wildly inaccurate would have been welcome. For example, it is pointed out that there was a tendency to assume that a large tumour was more malignant than a small one, without indicating whether or not this is actually the case. In other respects, Kaartinen's study of eighteenth-century breast cancer seems well-nigh exhaustive. She frequently goes beyond single or simple explanations in her willingness to explore a range of possibilities. For instance, Kaartinen considers what might have occurred in the minds of women with a breast lump who delayed seeing a physician, until it became life-threatening. The apparent silence and secrecy may not have been due to shame or embarrassment but simply because they were exploring other options, not least the understandable hope that it might go away of its own accord. There is much here with which the modern woman can identify. Since the eighteenth century is associated with sensibility, it is 
appropriate that this book has such a great capacity for generating empathy with its readers, who cannot fail to shudder with horror over the torture and suffering undergone by countless numbers of early modern women, forced to endure this devastating disease without the pain-relief of today and the interventions of modern medicine. 